\title{
Evaluation of Cosmetic Appearance and Ocular Motility Following Evisceration Surgery
}

\author{
OSAMA E. SHALABY, M.D.; AMR M. AWARA, M.D.; HEBA M. SHAFIK, M.D. and \\ HOSSAM M.F. DAWOUD, M.B.B.Ch.
}

The Department of Ophthalmology, Faculty of Medicine, Tanta University

\begin{abstract}
Background: Evisceration is a surgical technique that is used for cosmetic and curative reasons in many ocular diseases such as phthisis bulbi.

Aim of the Study: Evaluation of the cosmetic results and motility of the artificial prosthesis after two techniques of evisceration with insertion of prosthesis.

Patients and Methods: The study was carried out in ophthalmology department in Tanta University Hospital included 20 patients divided randomly into 2 equal groups. We underwent full history taking and acquired ophthalmological examination.
\end{abstract}

Operation and Follow-up: Evisceration of the eye with scleral quadrisection and insertion of an implant inside sclera in 10 patients (the first group) and addition of relaxing circumferential incision at posterior sclera in another 10 patients (the 2 nd group). Follow-up was carried out in 1 st day after operation, 1 week, 3 weeks and 6 weeks.

Results: Postoperative superior sulcus deformity difference between 2 groups was statistically significant $(p$-value $=0.031)$ and it was markedly deformed in $40 \%$ of cases in group 1 and $20 \%$ in group 2. Palpebral fissure height had also statistically significant difference between 2 groups $(p$-value $=0.030)$. enophthalmos was significantly reduced in the 2 nd group (mean $=0.700 \pm 0.483)$ in comparison to the 1 st group (mean= $1.700 \pm 1.059)$.

Conclusion and Recommendations: Performing relaxing posterior sclerotomies with evisceration surgeries allows insertion of larger implant with no increased risk of extrusion and this technique improves cosmetic appearance and motility of the prosthesis.

Key Words: Evisceration-Sclerotomies - Implants.

\section{Introduction}

EVISCERATION is a surgical technique that is used for certain ocular diseases such as phthisis

Correspondence to: Dr. Osama E. Shalaby, The Department of Ophthalmology, Faculty of Medicine, Tanta University bulbi, this technique involves removal of the intraocular contents, including the cornea, lens, uvea, retina and vitreous, while leaving the sclera and extraocular orbital anatomy intact [1].

Evisceration is preferred over enucleation because in evisceration, the orbital anatomy (including the muscular insertions), volume, and socket motility is preserved leading to better cosmetic result, superior mobility for the prosthesis, and lower risk of intracranial infection or extrusion of orbital implant [2].

Evisceration can be done with or without orbital implants, evisceration with orbital implant necessitates certain techniques to insert the ball like formation of four scleral petals for insertion of adequate size of orbital implants to avoid anophthalmic socket syndrome [3].

Orbital implants can be used in both evisceration and enucleation procedures and they have many types such as polymethyl methacrylate (PMMA), glass, and silicone spheres (nonintegrated implants) which do not allow in-growth of organic tissue into their inorganic substance. Also there are integrated implants (porous) like hydroxyapatite, aluminum oxide, and polyethylene [4] .

Evisceration procedures have also many drawbacks like orbital implant extrusion and anophthalmic socket syndrome. These drawbacks mainly results from using of larger or smaller implants than the actually needed [5]

The main cause of implant extrusion is excessive tension on the wound and usage of larger implants. Many evisceration techniques have been described to decrease the tension on the wound like 4 petal scleral technique with posterior sclerotomies [6]. 


\section{Patients and Methods}

This prospective study was conducted in Tanta University Ophthalmology Hospital from 2017 to 2018 and was carried out on 20 patients who underwent evisceration with insertion of implants. These implants are either silicone made or acrylic in nature and no other type was used due to financial issues. Patients were divided into 2 groups equally by 10 patients in each group and they were selected randomly in each group by performing the first surgical technique (scleral quadrisection and insertion of an implant inside sclera) in ${ }^{\text {st }} 10$ patients who came to Tanta University hospital and then the 2 nd surgical technique (as first group and addition of relaxing circumferential incision at posterior sclera in the other 10 patients.

Patients included in the study are the patients indicated for evisceration. Patients younger than 18 years old, with infectious causes and intraocular tumor are excluded from the study.

Full history taking including previous surgeries, full ophthalmological examination of the diseased eye by slit lamp, external appearance scars, evaluation of ocular motility, evaluation of conjunctival fornices, lid examination for entropion, ectropion $\&$ levator function and sclera for staphyloma are done to all patients in the study.

Also ultrasound and axial length was done if the condition of the diseased eye allowed that. Examination of the other eye was including also slit lamp and biometry in all patients.

\section{Operative procedure:}

Evisceration of the eye was done by limbal incision and removal of the cornea and removal of all intraocular contents. Insertion of an implant either silicone or acrylic implants through scleral quadrisection and insertion of the implant inside the sclera alone in one group or by adding relaxing circumferential incision at posterior sclera and insertion of the implant through in the other group.

Selection of the implant size was done by taking axial length from the other eye and using ball sizers during the operation.

\section{Post-operative follow-up}

Postoperative follow-up of the patients was done at the outpatient clinic for edema, ecchymosis, entropion, ectropion and the scar. Artificial prosthesis placement was done 6 weeks post-operative.

Examination and evaluation of the patients in the postoperative visits was done by assessment of palpebral fissure height, superior sulcus evaluation, degree of movement of both eye ball and evaluation of motility after artificial Prosthesis placement, enopthalmos and lower fornix depth.

\section{Results}

This study was conducted on 20 patients (14 male and 6 females). The mean age of these patients was 55.1 years (range from 29 to 70 years).

This study involved different causes of evisceration; 4 cases of atrophia bulbi, 10 cases of blind painful eye, 2 cases of trauma and 4 cases of anterior staphyloma.

In the study we used 2 types of non-porous implants. They are silicone and acrylic in nature. 20 implants are used in the study and they were 14 silicone and 6 acrylic implants and sizes of the used implants were between $16 \mathrm{~mm}$ and $22 \mathrm{~mm}$ with a mean of $18.6 \mathrm{~mm}$ as shown in Table (1).

Axial length was done for all cases in the other eye. The readings ranged from $21.29 \mathrm{~mm}$ to 27.36 $\mathrm{mm}$. mean value for axial length was $24.17 \mathrm{~mm}$ with standard deviation of 1.59 as shown in Table (2).

Correlation between axial length and implant size:

This study showed a statistically significant relation between axial length taken from the patients and changes in implant sizes used in the study as shown in $p$-value. There was also a significant positive correlation between them as shown by Pearson correlation coefficient $(r)$ as shown also in the following Table (3).

Relation between surgical technique and superior sulcus deformity:

In this study, there was a statistically significant relation between the technique of implantation used in 2 groups and superior sulcus deformity in patients included in the study as shown in Table (4).

Relation between surgical technique and palpebral fissure height:

In this study, there was a statistically significant relation between the technique of implantation used in 2 groups and palpebral fissure height estimated in patients included in the study as shown in Table (5).

Relation between surgical technique and enophthalmos:

In this study, there was a statistically significant relation between the technique of implantation 
used in 2 groups and enophthalmos estimated in patients included in the study as in Table (6).

\section{Relation between surgical technique and lower} fornix depth:

In this study, there was a statistically significant relation between the technique of implantation used in 2 groups and lower fornix depth in patients included in the study as shown in Table (7).

Relation between surgical technique and prosthesis mobility:

In this study, there was a statistically significant relation between the technique of implantation used in 2 groups and degree of motility of prosthesis estimated in patients included in the study as shown in the Table (8).

Relation between size of the implant and superior sulcus deformity in each surgical technique of implantation:

In this study, there was no statistically significant relation between the size of implant used in each technique of implantation and superior sulcus deformity estimated in patients included in the study as shown in the Table (9).

Relation between size of the implant and palpebral fissure height in each surgical technique of implantation:

In this study, there was no statistically significant relation between the size of implant used in each technique of implantation and palpebral fissure height estimated in patients included in the study as shown in the Table (10).

Relation between size of the implant and enophthalmos in each surgical technique of implantation:

In this study, there was a statistically significant relation between the size of implant used and surgical technique used in group one with negative correlation between them and no statistically significant relation between the size of implant used and surgical technique used in group 2 of patients included in the study as shown in the Table (11).

Relation between size of the implant and lower fornix depth in each surgical technique of implantation:

In this study, there was no statistically significant relation between the size of implant used in each technique of implantation and lower fornix examination in patients included in the study as shown in the Table (12).
Relation between size of the implant and degree of mobility of prosthesis in each surgical technique of implantation:

In this study, there was no statistically significant relation between the size of implant used in each technique of implantation and degree of prosthesis motility in patients included in the study as shown in Table (13).

Table (1): This table shows different sizes of implants used in the study.

\begin{tabular}{ccc}
\hline & \multicolumn{2}{c}{ Descriptive Statistics } \\
\cline { 2 - 3 } & Range & Mean \pm SD \\
\hline Size & $16-22$ & $18.600 \pm 1.603$ \\
\hline
\end{tabular}

Table (2): This table shows axial length reading range and mean in the study.

\begin{tabular}{lcc}
\hline & Range & Mean \pm SD \\
\hline Biometry & $21.29-27.36$ & $24.1765 \pm 1.592$ \\
\hline
\end{tabular}

Table (3): This table shows details of correlation between axial length and implant size.

\begin{tabular}{ccc}
\hline & \multicolumn{2}{c}{ Correlations } \\
\cline { 2 - 3 } & \multicolumn{2}{c}{ Axial length } \\
\cline { 2 - 3 } & $r$ & $p$-value \\
\hline Size & 0.941 & $<0.001^{*}$ \\
\hline
\end{tabular}

Table (4): This table shows the relation between technique of implantation and superior sulcus deformity in patients.

\begin{tabular}{|c|c|c|c|c|c|c|c|c|}
\hline \multirow{3}{*}{$\begin{array}{l}\text { Superior } \\
\text { sulcus } \\
\text { deformity }\end{array}$} & \multicolumn{6}{|c|}{ Surgery } & \multirow{2}{*}{\multicolumn{2}{|c|}{ Chi-Square }} \\
\hline & \multirow{2}{*}{\multicolumn{2}{|c|}{$\frac{\text { Group I }}{\mathrm{N} \% \mathbf{o}}$}} & \multicolumn{2}{|c|}{ Group II } & \multicolumn{2}{|c|}{ Total } & & \\
\hline & & & $\mathrm{N}$ & $\%$ & $\mathrm{~N}$ & $\%$ & $X^{2}$ & $p$-value \\
\hline No & 1 & 10 & 3 & 30 & 4 & 20 & \multirow{3}{*}{6.927} & \multirow{3}{*}{$0.031 *$} \\
\hline Mild & 5 & 50 & 7 & 70 & 12 & 60 & & \\
\hline Marked & 4 & 40 & 0 & 0 & 4 & 20 & & \\
\hline Total & 10 & 100 & 10 & 100 & 20 & 100 & & \\
\hline
\end{tabular}

Table (5): This table shows the relation between technique of implantation and palpebral fissure height in patients.

\begin{tabular}{|c|c|c|c|c|c|c|c|c|}
\hline \multirow{3}{*}{$\begin{array}{l}\text { Palpebral } \\
\text { fissure } \\
\text { height }\end{array}$} & \multicolumn{6}{|c|}{ Surgery } & \multirow{2}{*}{\multicolumn{2}{|c|}{ Chi-Square }} \\
\hline & \multirow{2}{*}{\multicolumn{2}{|c|}{$\frac{\text { Group I }}{\mathrm{No} \%}$}} & \multicolumn{4}{|c|}{ Group II Total } & & \\
\hline & & & $\mathrm{N}$ & $\%$ & $\mathrm{~N}$ & $\%$ & $\mathrm{X}^{2}$ & $p$-value \\
\hline No & 2 & 20 & 5 & 50 & 7 & 35 & \multirow{3}{*}{6.985} & \multirow{3}{*}{$0.030^{*}$} \\
\hline Mild & 4 & 40 & 5 & 50 & 9 & 45 & & \\
\hline Moderate & 4 & 40 & 0 & 0 & 4 & 20 & & \\
\hline Total & 10 & 100 & 10 & 100 & 20 & 100 & & \\
\hline
\end{tabular}


Table (6): This table shows the relation between technique of implantation and enophthalmos in patients.

\begin{tabular}{llllll}
\hline \multirow{2}{*}{ Enophthalmos } & \multicolumn{2}{c}{ Surgery } & & \multicolumn{2}{c}{$t$-test } \\
\cline { 2 - 3 } & Group I & Group II & & $t$ & $p$-value \\
\hline Range & $0-3 \mathrm{~mm}$ & $0-1 \mathrm{~mm}$ & & \\
Mean \pm SD & $1.700 \pm 1.059$ & $0.700 \pm 0.483$ & & 2.716 & $0.014 *$ \\
\hline
\end{tabular}

Table (7): This table shows the relation between technique of implantation and lower fornix depth in patients.

\begin{tabular}{|c|c|c|c|c|c|c|c|}
\hline \multirow{3}{*}{$\begin{array}{l}\text { Lower } \\
\text { fornix } \\
\text { depth }\end{array}$} & \multicolumn{5}{|c|}{ Surgery } & \multirow{2}{*}{\multicolumn{2}{|c|}{ Chi-Square }} \\
\hline & \multirow{2}{*}{$\frac{\text { Group I }}{\mathrm{N} \%}$} & \multicolumn{4}{|c|}{ Group II Total } & & \\
\hline & & $\mathrm{N}$ & $\%$ & $\mathrm{~N}$ & $\%$ & $\mathrm{X} 2$ & $p$-value \\
\hline Very shallow & 50 & 0 & 0 & 5 & 25 & & \\
\hline Shallow & 40 & 7 & 70 & 11 & 55 & 6.818 & $0.033 *$ \\
\hline Enough depth & 10 & 3 & 30 & 4 & 20 & & \\
\hline Total & 10100 & 10 & 100 & 20 & 100 & & \\
\hline
\end{tabular}

Table (8): This table shows the relation between technique of implantation and degree of mobility of prosthesis in patients.

\begin{tabular}{|c|c|c|c|c|c|c|c|c|}
\hline \multirow{3}{*}{$\begin{array}{l}\text { Degree of } \\
\text { mobility of } \\
\text { prosthesis }\end{array}$} & \multicolumn{6}{|c|}{ Surgery } & \multirow{2}{*}{\multicolumn{2}{|c|}{ Chi-Square }} \\
\hline & \multirow{2}{*}{\multicolumn{2}{|c|}{$\frac{\text { Group I }}{\mathrm{N} \%}$}} & \multicolumn{4}{|c|}{ Group II Total } & & \\
\hline & & & $\mathrm{N}$ & $\%$ & $\mathrm{~N}$ & $\%$ & $\mathrm{X} 2$ & $p$-value \\
\hline Poor & 6 & 60 & 0 & 0 & 6 & 30 & & \\
\hline Fair & 4 & 40 & 7 & 70 & 11 & 55 & 9.818 & $0.007 *$ \\
\hline Good & 0 & 0 & 3 & 30 & 3 & 15 & & \\
\hline Total & 10 & 100 & 10 & 100 & 20 & 100 & & \\
\hline
\end{tabular}

Table (9): This table shows the relation between size of implants and superior sulcus deformity used in each surgical technique of implantation.

\begin{tabular}{lllllll}
\hline \multirow{2}{*}{ Surgery } & $\begin{array}{c}\text { Superior } \\
\text { sulcus } \\
\text { deformity }\end{array}$ & N Mean \pm SD & & F or $t$ & $p$-value \\
\cline { 3 - 4 } \cline { 5 - 6 } Group I & No & 1 & $20.000 \pm 0.000$ & & 1.462 & 0.295 \\
& Mild & 5 & $18.800 \pm 1.095$ & & & \multicolumn{2}{c}{$\begin{array}{c}\text { ANOVA or } \\
\text { Group II }\end{array}$} \\
& Marked & 4 & $17.500 \pm 1.915$ & & \\
& No & 3 & $18.000 \pm 2.000$ & -0.980 & 0.356 \\
& Mild & 7 & $19.143 \pm 1.574$ & & \\
\hline
\end{tabular}

Table (10): This table shows the relation between size of implants and superior sulcus deformity used in each surgical technique of implantation.

\begin{tabular}{|c|c|c|c|c|}
\hline \multirow{2}{*}{ Surgery } & \multirow{2}{*}{$\begin{array}{l}\text { Palpebral } \\
\text { fissure } \\
\text { height }\end{array}$} & \multirow{2}{*}{$\frac{\text { Size }}{\text { N Mean } \pm \text { SD }}$} & \multicolumn{2}{|c|}{$\begin{array}{c}\text { ANOVA or } \\
t \text {-test }\end{array}$} \\
\hline & & & $\mathrm{F}$ or $t$ & $p$-value \\
\hline \multirow[t]{3}{*}{ Group I } & No & $219.000 \pm 1.414$ & 1.112 & 0.381 \\
\hline & Mild & $419.000 \pm 1.155$ & & \\
\hline & Moderate & $417.500 \pm 1.915$ & & \\
\hline \multirow[t]{2}{*}{ Group II } & No & $518.400 \pm 1.673$ & -0.730 & 0.486 \\
\hline & Mild & 5 19.200土1.789 & & \\
\hline
\end{tabular}

Table (11): This table shows the relation between size of implants and enopthalmos in each implantation technique used in both groups of patients.

\begin{tabular}{cll}
\hline \multirow{2}{*}{ Surgery } & \multicolumn{2}{c}{ Correlations } \\
\cline { 2 - 3 } & \multicolumn{2}{c}{ Size } \\
\cline { 2 - 3 } & $r$ & $p$-value \\
\hline Group I & -0.718 & $0.019^{*}$ \\
Group II & 0.327 & 0.356 \\
\hline
\end{tabular}

Table (12): This table shows the relation between size of implants and lower fornix examination used in each surgical technique of implantation.

\begin{tabular}{cccccc}
\hline \multirow{2}{*}{ Surgery } & $\begin{array}{c}\text { Lower } \\
\text { fornix } \\
\text { examination }\end{array}$ & & \multicolumn{2}{c}{ Size } & \multicolumn{2}{c}{$\begin{array}{c}\text { ANOVA or } \\
\boldsymbol{t} \text {-test }\end{array}$} \\
\cline { 3 - 6 } & $\mathrm{N}$ & Mean $\pm \mathrm{SD}$ & $\mathrm{F}$ or $\boldsymbol{t}$ & $\boldsymbol{p}$-value \\
\hline Group I & Very shallow & 5 & $17.600 \pm 1.673$ & 1.658 & 0.257 \\
& Shallow & 4 & $19.000 \pm 1.155$ & & \\
& Enough depth & 1 & $20.000 \pm 0.000$ & & \\
\multirow{5}{*}{ Group II Shallow } & 7 & $19.143 \pm 1.574$ & 0.980 & 0.356 \\
& Enough depth & 3 & $18.000 \pm 2.000$ & & \\
\hline
\end{tabular}

Table (13): This table shows the relation between size of implants and degree of mobility of the prosthesis used in each surgical technique of implantation.

\begin{tabular}{lccccc}
\hline \multirow{2}{*}{ Surgery } & \multirow{2}{*}{$\begin{array}{c}\text { Degree of } \\
\text { prosthesis } \\
\text { mobility }\end{array}$} & \multicolumn{2}{c}{ Size } & \multicolumn{2}{c}{$t$-test } \\
\cline { 3 - 6 } & N & Mean \pm SD & $t$ & $p$-value \\
\hline Group I & Poor & 6 & $18.000 \pm 1.789$ & -0.980 & 0.356 \\
& Fair & 4 & $19.000 \pm 1.155$ & & \\
Group II & Fair & 7 & $19.143 \pm 1.574$ & 0.980 & 0.356 \\
& Good & 3 & $18.000 \pm 2.000$ & & \\
\hline
\end{tabular}

\section{Discussion}

Evisceration is a common surgical procedure by which intraocular contents are removed with preservation of sclera, extraocular muscles and orbital adnexa. In comparison with enucleation, evisceration is better due to relative preservation of tissues and this leads to better cosmetic result. It also can be combined with insertion of an implant into the eviscerated cavity for orbital volume replacement. Common causes of evisceration include endophthalmitis, expulsive hemorrhage and blind painful eye. In our study, the most common cause of evisceration was due to blind painful eye and they were 10 cases ( $50 \%$ of patients). Other causes included 4 cases anterior staphyloma $(20 \%$ of patients), 4 cases of atrophia bulbi (20\% of patients) and 2 cases of trauma (10\% of cases). $[1,2]$.

Most surgeons prefer immediate placement of the implants in a single surgery due to simplicity and cost-effectiveness but some surgeons choose to place the implant in a secondary staged procedure 
days to weeks after the initial evisceration, particularly in the setting of acute infection, believing that the rates of implant extrusion may be higher with primary implantation at the time of evisceration. In our study, we performed evisceration with immediate placement of the implant in the same session [3].

In our study non-porous non-integrated implants were used. We used silicone implants in 14 cases (70\% of patients) and the other 6 cases acrylic implants were used (30\% of patients).

In the past, standard evisceration techniques typically only allow placement of a 13-16-mm spherical implant $[7,8]$. To achieve optimum volume replacement with insertion of suitable large implant and reducing the tension on scleral flaps, the evisceration technique has undergone several modifications. Yang et al., [9] described scleral quadrisection after evisceration, without releasing it from the optic nerve. Massry and Holds [10] performed 2 full thickness sclerotomies from the anterior limbus incision to the optic nerve in inferonasal and superotemporal quadrants. Kim et al., [4] used evisceration with four anterior full thickness scleral relaxing incisions between the recti muscles insertion to the equator, and circumferential posterior sclerotomy surrounding the optic nerve for $330^{\circ}$. Sales-Sanz and Sanz-Lopez [2] described the four petals evisceration. They performed four sclerotomies from the limbus, between the recti muscles to the optic nerve with releasing the scleral flaps from the optic nerve. Huang et al., [1] described a similar technique involving scleral quadrisection and suturing the implant with each rectus muscle through the scleral petal.

In this study, we used evisceration with scleral quadrisection and insertion of an implant inside the sclera in 10 cases (50\% of patients) and in the other technique, we added relaxing posterior sclerotomies in other 10 cases ( $50 \%$ of patients) to compare statistically between results of both techniques.

Implant size has traditionally been determined on an empiric basis. Insertion of an implant of an inappropriate size results in a variety of complications. Placement of an abnormal small implant causes volume deficit in the orbit leading to deep superior sulcus while excessively large implants increase the risk of implant extrusion and compromise the fitting and retention of the prosthesis. For accurate determination of the implant size, Kaltreider and Lucarelli [5] described a simple formula which allowed good volume replacement. They used implant diameter equals axial length of the contralateral eye- $3 \mathrm{~mm}$ that results from the evisceration procedure.

In our study, axial length was taken from other eye in all patients and the size and type of implant is chosen by operator preference. Ball sizer is used in patients intraoperative to assess the size of the opening in the sclera to allow insertion of the predetermined implant.

A common complication associated with orbital implants is implant extrusion. The actual incidences of implant extrusion were variable in different reports using different surgical techniques. Viswanathan et al., [11] in a national survey recorded 3\% rate of extrusion of the implant after evisceration (4 of 128 cases). Detailed analysis of this complication was limited in this survey due to questionnaire design as specific clinical and surgical details were not requested. The main risk factors for exposure and extrusion of the implant are inadequate surgical technique, covering the implant with high tension, and persistent conjunctival inflammation [2].

Despite placement of a large implant, patients may still develop a "sunken-in" appearance. Several mechanisms have been proposed for deep superior sulcus and subsequent ptosis.

In this study, there is a statistically significant relation between the technique of surgery used in 2 groups and superior sulcus deformity in patients included in the study ( $p$-value: 0.03 ) and this difference is supposed to be due to adequate volume replacement. Also in this study, there is a statistically significant relation between the technique of surgery used in 2 groups and other outcomes like palpebral fissure height, enophthalmos, superior lower fornix and degree of mobility of the prosthesis in patients included in the study.

In conclusion, performing relaxing posterior sclerotomies increases the space and allows larger sizes of implants to be used. This technique facilitates the insertion of such large implant without tension on scleral flaps avoiding implant exposure and improving surgical cosmetic outcome.

\section{References}

1- HUANG D., YU Y., LU R., YANG H. and CAI J.: A modified evisceration technique with scleral quadrisection and porous polyethylene implantation. J. of Ophthalmology, 147 (5): 924-8, 8.e1-3, 2009.

2- SALES-SANZ M. and SANZ-LOPEZ A.: Four-petal evisceration: a new technique. Ophthalmic. Plast. Reconstr. Surg., 23 (5): 389-92, 2007. 
3- BLAYDON S.M., SHEPLER T.R., NEUHAUS R.W., WHITE W.L. and SHORE J.W.: The porous polyethylene (Medpor) spherical orbital implant: A retrospective study of 136 cases. Ophthalmic. Plast. Reconstr. Surg., 19 (5): 364-71, 2003.

4- KIM K.H., LEE H., PARK M., CHI M., LEE J. and BAEK S.: Evisceration with four anterior relaxing incisions and circumferential posterior sclerotomies with porous polyethylene orbital implants: An 8-year study. Acta. Ophthalmologica., 89 (7): 686-90, 2011.

5- KALTREIDER S.A. and LUCARELLI M.J.: A simple algorithm for selection of implant size for enucleation and evisceration: A prospective study. Ophthalmic. Plast. Reconstr. Surg., 18 (5): 336-41, 2002.

6- ADAMS J.W., PAXTON L., DAWES K., BURLAK K., QUAYLE M. and MCMENAMIN P.G.: 3D printed reproductions of orbital dissections: A novel mode of visualising anatomy for trainees in ophthalmology or optometry. Br. J. Ophthalmol., 99 (9): 1162-7, 2015.

7- ZOLLI CL.: Implant extrusion in eviscerations. Annals of Ophthalmology, 20 (4): 127-32, 35, 1988.

8- SOLL D.B.: The anophthalmic socket. Ophthalmology, 89 (5): 407-23, 1982.

9- YANG J.G., KHWARG Si., WEE W.R., KIM D.M. and LEE J.H.: Hydroxyapatite implantation with scleral quadrisection after evisceration. Ophthalmic Surgery and Lasers, 28 (11): 915-9, 1997.

10-MASSRY G.G. and HOLDS J.B.: Evisceration with scleral modification. Ophthalmic. Plast. Reconstr. Surg., 17 (1): 42-7, 2001.

11- VISWANATHAN P., SAGOO M.S. and OLVER J.M.: UK national survey of enucleation, evisceration and orbital implant trends. Br. J. Ophthalmol., 91(5): 616-9, 2007.

\title{
تقييم المظهر الجمالى للعين وحركتها ما بعل عملية التفريغ
}

\author{
أجريت الدراسة على •rمريضاً متوسط أعمارهم ا-00 سنة وكانت عوامل الأنتقاء كالآتى:

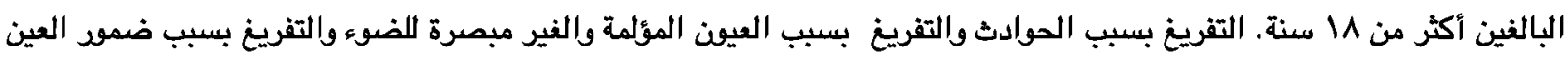 \\ والتفريغ بسبب العنية الأمامية. \\ وكانت عوامل الأستبعاد كالآتى:

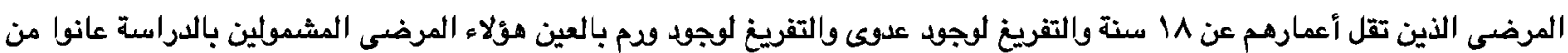

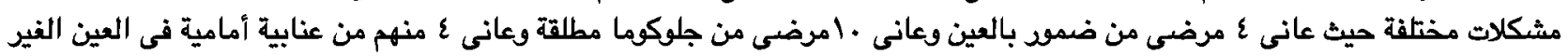 \\ مبصرة الضضوء وعانى بامن إصابة بالعين. \\ تم إستخدام • Y كدة بواقع عا كدة مصنوعة من السليكون و 7 كرات مصنوعة من مادة الاكريليك وكانت أحجامهم تتراوح من 17 مم إلى

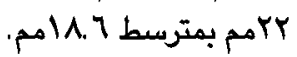

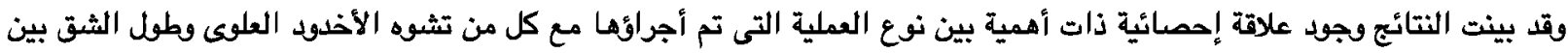

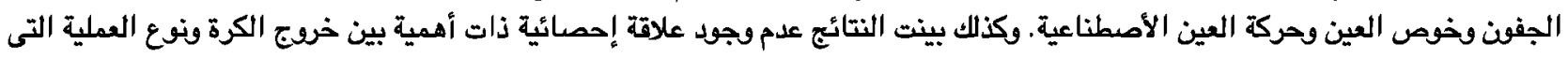 \\ تم إجراؤها.
}

أما بالنسبة لحجم الكرة التى تم زدعها فلم توجد علاقة إحصائية ذات أهمية بينها وبين كل ما سبق من تشوه ولأخدو العلوى وطول الثق

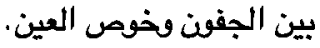

